\title{
How to Write Good Quality Contextual Science Questions: Criteria and Myths*
}

\author{
Rıdvan ELMAS ${ }^{* *}$
}

Received: 25 June 2015

\author{
Ali ERYILMAZ ${ }^{* * *}$
}

\begin{abstract}
The goal of this study is to set criteria for writing good contextual questions. This is a theoretical research work based on an extensive literature review. Extensive literature comprised of reviewing leading data bases, educational journals, and proceedings. All the collected materials from these resources were read, compiled, analyzed, interpreted, and synthesized. The information gathered from these sources were systematically used as an input to generate criteria for writing good contextual questions. Eventually, 3 main criteria and 11 sub-criteria were generated from these studies. Besides, the difference between contextual and idealized questions was presented comparatively. As a final step, common misunderstandings i.e., myths related to contextual questions were determined and presented in detail. This study can be seen as a how-to-guide to all stake holders of education for writing good contextual questions.
\end{abstract}

Keywords: context, context based education, contextual teaching and learning, contextual questions, questions

\section{Extended Abstract}

Purpose and Significance: The goal of this study is to set criteria for writing good contextual questions based on relevant literature. Contextual teaching and learning (CTL) is a very prominent approach. CTL approach is interpreted and developed by a wide array of researchers from many different countries with similar perspectives. During the implementation process, practitioners should need to use contextual questions somehow though there are very limited number of studies indicating how to generate good contextual questions.

Methods: This is a theoretical research work based on an extensive literature review. Extensive literature comprised of reviewing leading data bases, educational journals and proceedings. All the collected materials from these resources were read, compiled, analyzed, interpreted, and synthesized. The information was gathered from these sources were systematically used as an input for discussions to generate criteria for writing good contextual questions.

\footnotetext{
* This article was presented at International Conference on Chemical Education (ICCE), July 13-18, Toronto, Canada.

** Corresponding Author: Assist. Prof. Dr., Afyon Kocatepe University, Afyonkarahisar, Turkey, relmas@aku.edu.tr

Assoc. Prof. Dr., Middle East Technical University, School of Education, eryilmaz@metu.edu.tr

**** This study was supported by Afyon Kocatepe University Scientific Research Projects Unit (BAP), (14.HIZ.DES.37)
} 
Results: 3 main criteria and 11 sub-criteria were generated from these studies. Besides, the differences between contextual and idealized questions were presented comparatively. As a final step, common misunderstandings i.e., myths related to contextual questions were determined and presented in detail. This study can be seen as a how-to-guide to all stake holders of education for writing good contextual questions.

The three main criteria for writing a good contextual question are;

1- Question should contain an issue (problem) of individual or public concern. (6 subcriteria)

2- While generating the question, science concepts, facts, formulas and laws are required to be interwoven with the context to form a holistic pattern. (3 sub-criteria)

3- Answer of the question should be found as a result of a thinking process not mere memorization. (2 sub-criteria)

In order to be counted as contextual, the item should possess the three criteria above. In addition, the more sub-criteria included in the question the better quality contextual questions are created.

Discussion and Conclusions: The developed 3 main and 11 sub criteria about contextual questions can be easily used as a guideline for generating contextual questions. Contextual questions can be used as a good alternative to idealized questions. 


\section{Bağlam Temelli Fen Soru Yazımı: Kriterler ve Efsaneler}

\author{
Rıdvan ELMAS ${ }^{* *}$
}

\author{
Ali ERYILMAZ ${ }^{* * *}$
}

Makale Gönderme Tarihi: 25 Haziran 2015

Makale Kabul Tarihi: 7 Ekim 2015

ÖZET: Bağlam temelli soru fen bilgisinin bir bağlam ile örüntülenerek sunulduğu sorudur. Bu çalışmanın amacı bağlam temelli soruların yazılabilmesi için uyulması gereken ölçütlerin belirlenmesidir. Bu ölçütler belirlenirken alan yazındaki konu ile ilgili çalışmalar taranmış, belirlenen çalışmalar detaylı incelenmiş ve sonuçları ilgili ölçütlerin belirlenmesi için sentezlenmiştir. Bağlam temelli olarak hazırlanan soruların daha nitelikli, net ve kaliteli olması için gerekli olan 3 temel ve 11 alt ölçüt belirlenmiştir. İdealleştirilmiş sorular fen bilgisinin bilgi ve problem çözümü odaklı olarak kurgulandığı ve bağlam sunma kaygısından uzak olan sorulardır. Belirlenen ölçütler ile birlikte bağlam temelli sorular idealleştirilmiş sorular ile karşılaştırılmış ve farkları ortaya konmuştur. Son adımda bağlam temelli soru niteliği, netliği ve kalitesi ile ilgili olmayan fakat bu konuda genel yargı oluşturmuş yanlışlar (efsaneler) ortaya konmuş ve bunlar detaylı bir şekilde açıklanmıştır. Bu çalışma bağlam temelli soru yazımı ile ilgilenmek isteyen tüm eğitim paydaşlarına rehber olacak niteliktedir.

Anahtar sözcükler: bağlam, bağlam temelli eğitim, yaşam temelli eğitim, bağlam temelli soru

\section{Giriș}

Bağlam temelli yaklaşım geleneksel yöntemlerden sıkılan ve ilgisini kaybeden öğrencilere ve öğretmenlere günlük hayatın içinden alınmış bağlamlarla yeni bir öğrenme ortamı sunmaktadır (Christensson ve Sjöström, 2014; Mahaffy, 2015; Sjöström ve Talanquer, 2014). Bu uygulamaya bağlam içerisinde günlük bir sorun ile başlanır ve bu sorunun çözümü ile ilgili sorular sorulur (Broman ve Parchmann, 2014). Bu sorulara cevap bulmak için fen bilgisine ihtiyaç duyulur, ilgili konular öğrenildikten sonra sorulara cevaplar verilir ve aynı konu ile ilgili diğer bir sorun üzerinden ders devam eder. Bu konuları niye öğreniyorum sorusuna konu öğrenilmeden önce cevap verilmesi sağlanır. Böylece fen bilimlerinin kişisel ve günlük hayatla olan ilişkisi kurulmuş olur. Bağlamlar ile hayatın içindeki olayları, olguları ve nesneleri de anlamış oluruz. Bu yaklaşıma bağlam (yaşam) temelli yaklaşım diyoruz (Elmas, 2012; Peşman, 2012).

Bağlam temelli yaklaşıma uygun stratejiler kullanılarak işlenen derslerin değerlendirilmesinde bağlam temelli soruların kullanılması da gündeme gelmektedir. Bugüne kadar genel olarak fen ders çıktılarının değerlendirilmesinde kullanılan klasik soruların fen bilimlerini idealize ettiği ve gerçekte hayatla bağını öğrenci ve öğretmenlere kurduramadığı açıktır (Benckert, 1997). Bu nedenle bağlamlar üzerinden kurgulanmış ve öğrencilere daha anlamlı gelen sorularının da artık kullanılması gerekmektedir (Cumming ve Maxwell, 1999). Bununla birlikte bağlam temelli olarak

\footnotetext{
* Bu çalışma International Conference on Chemical Education (ICCE) , July 13-18, Toronto, Canada da sözlü bildiri olarak sunulmuştur.

*** Sorumlu Yazar: Yrd. Doç. Dr., Afyon Kocatepe Üniversitesi, Afyonkarahisar, relmas@aku.edu.tr

*** Doç. Dr., Orta Doğu Teknik Üniversitesi, eryilmaz@metu.edu.tr

**** Bu çalışma Afyon Kocatepe Üniversitesi Bilimsel Araştırma Projeleri Birimi (14.HIZ.DES.37) tarafından desteklenmiştir.
} 
hazırlanan ders tasarımlarının çıktılarını ölçerken ağırlıklı olarak bağlam temelli soruların kullanılmasına olan ihtiyaçta açıktır (Bennett, Lubben ve Hogarth, 2007).

Sorularda da bağlamın kullanılması önemlidir. Bunun nedeni öğrencileri sınıfta bağlam içinde öğrendikleri bilimsel bilgileri diğer bağlamlara da uygulayabildiklerinin yani transfer edebildiklerinin görülmesi açısından kritiktir (Ahmed ve Pollitt, 2007). Bu sayede bağlamlar içinde öğrenilen fen bilgisinin diğer bağlamlara ya da durumlara ne oranda aktarılabileceği belirlenmiş olacaktır. Bununla birlikte bağlam kullanılmadan hazırlanan birçok soru ezbere, formüllere ve kitabi bilgilere dayanarak öğrenciyi düşünce süreçlerinden geçirmeden cevabına gidilebilecek soru türleridir (Bellocchi, King, ve Ritchie, 2011). Bunlar da öğrenciye kısmen fayda sağlamaktadırlar. Ayrıca fen sorularının bağlam içerisinde sorulması soruların somutlaştırılmasına yardımcı olur ve öğrenciler zihinlerinde soruları canlandırabilirler (Rennie ve Parker, 1996).

Yapılan bazı çalışmalarda öğrenciler bağlam temelli sorularla yapılan değerlendirmelerde klasik sorularla yapılan değerlendirme faaliyetlerine göre ya aynı oranda (Tekbıyık ve Akdeniz, 2010) ya da daha başarılı çıkmışlardır (Rennie ve Parker, 1996; Benckert, 1997). Bunlarla birlikte bağlam temelli eğitim alan öğrenciler eğer bağlam temelli sorularla ölçülürse daha başarılı olmaktadırlar (Bennett, Lubben ve Hogarth, 2007). Genel olarak alan yazında bu konu ile ilgili sınırlı çalışma olduğunu bilinmekle birlikte çalışmaların sonuçlarının genellikle olumlu olduğu görülmektedir.

Sorularda bağlamın kullanılması bazı zorlukları ve dikkat edilmesi gereken hususları da beraberinde getirmektedir. Bunlar sorulardaki bağlama tanıdıklık, okuma yükü, odaklanma ve bağlamın soruda kullanılmasından kaynaklanan akıl yürütme süreçleri olarak sıralanabilir (Ahmed ve Pollitt, 2007). Bağlam temelli soruların ölçme ve değerlendirme süreçlerinde kullanılması için üretilirken bağlam seçimi kritik önem taşır. Seçilen bağlamın sorunun veya testin geçerliliğini tehlikeye düşürmemesi beklenir (Ahmed ve Pollitt, 2007; Bellocchi, King, ve Ritchie, 2011). Bu sebeple çalış1lan ögrenci grubunun ilgi ve düzeylerine uygun bağlamların bir ön çalışma ile belirlenmesi ve hazırlanan sorularda öğrencilere yakın ve ilgilerini çeken bağlamların kullanılması uygun olacaktır (Elmas, Bülbül ve Eryılmaz, 2011). Bağlam temelli sorularda soru bağlamla bir örüntü içinde oluşturulmaya çalışıldığından genellikle okuma yükü diğer sorulara göre daha fazladır bu sebeple bu tip soru köklerinde gereksiz detayların verilmesinden özellikle kaçınılmalıdır. Bununla birlikte bağlam temelli sorularda soru kurgulanırken çok dikkat edilmeli, bağlamın fen bilgisinin önüne geçmesine ve öğrencinin soruya değil bağlama odaklanması engellenmelidir (Shiu-sing, 2005). Bağlam temelli olarak hazırlanan sorular genelde bir düşünme süreci sonunda çözülürler bunun için bağlam temelli olarak hazırlanan soruların büyük bir kısmı gerçek hayat problemleridir (Hill, 1998).

Genel manada iyi kalitede yazılmış bağlam temelli bir soruyu çözmek için öğrencinin belli basamaklardan geçmesi beklenir. Bağlam temelli sorular oluşturulurken genel bir ön kural olarak öğrencinin bu basamaklardan geçirecek şekilde soruların yazılması gerekliliği akılda hep tutulmalıdır. Problem çözme basamakları Heller, Keith 
ve Anderson (1992) tarafından beş aşamalı olarak belirlenmiştir. Bu basamaklar aşağıda verilmiştir:

1. Öğrenci problemi sözel olarak anlayabilmeli ve hayal edebilmelidir.

2. Öğrenci problemi fen kavramları, kuralları ve kanunları ile çözümleyebilmeli ve ifade edebilmelidir.

3. Öğrencinin soruya nasıl bir çözüm üreteceği ile ilgili olarak planlama yapabilmelidir.

4. Öğrenci sorunun çözümüne yönelik olarak yaptığı planı uygulamaya koyabilmelidir.

5. Öğrenci bulduğu çözümün sorunun doğru çözümü olup olmadığını değerlendirebilmelidir.

$\mathrm{Bu}$ basamaklar kaliteli bir bağlam temelli sorunun çözümü esnasında öğrencilerin geçmesini beklediğimiz süreçlerdir.

Uzun süredir ülkemizde ağırlıklı olarak idealleştirilmiş (klasik) dediğimiz sembollerle ifade edilen ve fen bilimlerinin gerçek hayatla ilgisinin çok sınırlı tutulduğu sanki hayaller âlemin de yapılan soyut bir bilimmiş gibi yansıtan sorular kullanılmaktadır. Burada idealleştirmeden kastımız bir sorunun basitleştirilmesi ya da sorudaki bazı fen bilgilerinin (Sürtünme katsayısı gibi) ihmal edilmesi değildir. Fen bilimlerinin basitleştirilmesi ya da belli değerlerin ihmal edilmesinden ziyade sorularda fen bilgisinin soyut veya somut gerçek hayatla ilgilisi olmayan örnekler ve cisimler üzerinden kurgulanması olarak anlaşılmalıdır. İdealleştirilmiş sorular öğrencilerde bu tip sorularla ilgili zor, soyut ve sadece fen bilimleri ile ilgili olduğu şeklinde bir alg1 oluşmasına sebep olmaktadır ve genel olarak fen bilimlerine olan ilgiyi azaltmaktadır (Benckert, 1997). Bağlam temelli yaklaşımın Türkiye'de kabul görmesinin sonucu olarak fizik öğretim programının bağlam temelli yaklaşıma dayalı olarak hazırlanmasının denenmesi, idealleştirilmiş soru tipleri ile ilgili de sıkıntıları daha çok ön plana çıkmasına sebep olmuştur (Gülyurdu ve Eryılmaz, 2012). Bununla birlikte nitelikli bağlam temelli soru yazımında bir standart tutturulamamış ve özellikle öğretmenlerin bağlam temelli soru yazımı ile ilgili sorunları ön plana çıkmıştır (Kurnaz, 2013). Bu noktadan sonra bağlam temelli sorular ve fizik ders kitaplarındaki ağırlıkları ve nitelikleri de sorgulanmaya başlanmıştır (Gülyurdu ve Eryılmaz, 2012). Bununla birlikte idealleştirilmiş bir soru ile bağlam temelli bir soruyu ayıracak kesin çizginin nerden çizileceği bir sorun olarak ortaya çıkmaya başlamıştır. Bağlam temelli ve idealleştirilmiş soruların özellikleri ile ilgili genel bilgiler Tablo 1'de özetlenmiştir. 
Tablo 1

Bağlam Temelli ve İdealleştirilmiş Sorular

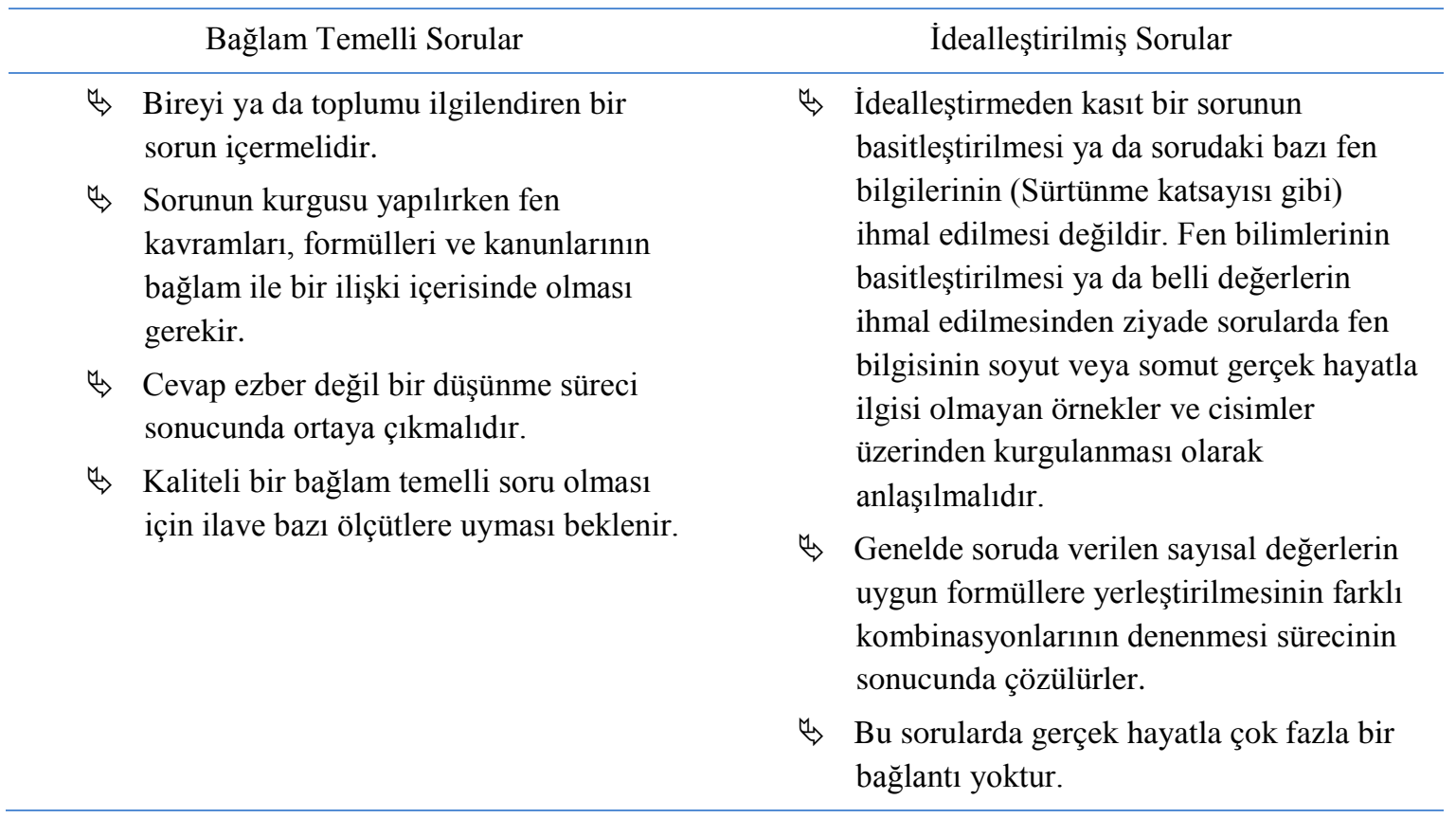

Bağlamın net bir tanımının ortaya konması birçok farklı alanda kullanıldığı için oldukça zordur (Akman, 2000). Goffman (1974) bağlamı incelenen olayı saran bir çerçeve ve olayın doğru bir şekilde yorumlanması için sunulan kaynaklar olarak tanımlamıştır. Harris (1988) ise bağlamı, olayların yorumlanmasında bize yardımcı olan sosyal ve kültürel yapıyı kapsayan bir deneyim olarak tanımlamıştır (Aktaran Akman, 2000). Daha güncel bir tanımı dilbilim dalında Duranti ve Goodwin (1992) tarafindan kültürel ve sosyal ortamına gömülmüş bir odak olay olarak yapılmıştır. Gilbert (2006) bu tanımdan yola çıkarak bu tanımdaki odak olayı bağlamın merkezi olarak açıklamış ve bir resmin, diyagramın ya da modelin kullanılması olarak tanımlamıştır. Gilbert (2006) ayrıca Duranti ve Goodwin'in vurguladığı bağlamın dört boyutunu kimya eğitime uyarlamış ve bunlara bağlamın öznitelikleri demiştir. Bu dört öznitelik aşağıda sıralanmıştır;

1. Çerçeve; olay yeri, hikâyenin geçtiği ortam: Bağlamın şekillendiği çevrenin tanımlanmasıdır.

2. Davranışlar; bağlamla ilgili gerçekleşmesi beklenen davranışlar: Bağlamın kullanılmasıyla öğrencilerin belli davranışları sergileyecekleri ve belli süreçlerden geçecekleri ön görülür.

3. Kimyasal konuşmalar: Bağlam ile ilgili olarak kullanılan bilimsel kavramlar, kanunlar ve kuralların işlenen ders içinde bağlam ile ilişkilendirilerek kullanılmasidir.

4. Durumla alakalı arka plan bilgisi: Bağlamın anlaşılabilmesi için bilinmesi gereken temel kavramlar ve kurallardır. Bağlamla birlikte öğrenilen yeni bilgilerin farklı bağlamlarda da kullanılabilmesi beklenir. 
Bir bağlamın eğitim ve öğretimde kullanılması için yukarıdaki dört özelliğin bu bağlam için tanımlanması kullanılan bağlamın eğitimsel değerini ve kullanılabilirliği göstermektedir.

Bağlamları genel olarak soyut ve somut bağlamlar ya da gerçek hayat bağlamları ve gerçek hayat dışındaki bağlamlar gibi temel iki gruba ayırabiliriz. Gerçek hayat bağlamları derken kastettiğimiz hayatımızın herhangi bir noktasında somut olarak karşılaşabileceğimiz ve bağlam olarak kullanılabilecek her türlü somut obje ile ilgili olaylar olarak düşünülebilir. Bu objelere örnek olarak insan, deniz, telefon, araba gibi birçok bağlam olma potansiyeli olan kavramlar sıralanabilir (Elmas, Bülbül, ve Eryılmaz, 2011). Gerçek hayat dışı bağlamlarda daha çok düşüncelerimizi kullanarak üretebileceğimiz ve hayal dünyamızda var olan soyut bağlamlardır. Bunlara en uygun örnek olarak fizikte kullanılan düşünce deneyleri verilebilir. Mesela 1şık hızıyla giden bir arabanın farları yandığında yolu aydınlatır mı sorusu düşünce deneylerine iyi bir örnektir. Bununla birlikte karıncaların binalar büyüklüğünde olması durumunda karıncanın hayatının bundan nasıl etkileneceği üzerinde planlanan bir derste yine soyut bir bağlam kullanılmış olur ki bir karıncanın bir bina büyüklüğünde olması ancak hayal edebileceğimiz bir bağlamdır.

Bağlam temelli soru niteliklerini sıralamadan önce sorunun temel soru yazma ölçütlerine uygun ve doğru olarak kurgulandığını varsaymaktayız. Bundan sonra birinci olarak soru bireyi ya da toplumu ilgilendiren bir sorun içermelidir. İkinci olarak sorunun kurgusu yapılırken fen kavramları, formülleri ve kanunlarının bağlam ile bir örüntü içerisinde olması gereklidir. Üçüncü ve son ölçütte cevabın ezbere değil bir düşünce süreci sonucunda ortaya çıkmalıdır. Bu üç kritik ölçüte uyan sorulara bağlam temelli sorular diyebiliriz. Bir bağlam temelli sorunun kaliteli bir bağlam temelli soru olarak adlandırılması için bu üç ölçüt altında verilen alt maddelerin de birçoğuna uyması beklenir (Tablo 2). Bir soru ölçütlerden ne kadar büyük bir kısmına dikkat edilerek hazırlanıyorsa sorunun kalitesi uyulan ölçüt sayısı ile doğru orantılı olarak artacaktır.

Nitelikli, anlaşılır ve kaliteli bağlam temelli soru yazımı yukarıda da anlatıldığı gibi ihtiyaç duyulan (Kurnaz, 2013; Tural, 2012), birçok süreci kapsayan ve farkl1 boyutlarda dikkat edilmesi gereken birçok husus içermektedir (Ahmed ve Pollitt, 2007; Tekbıyık ve Akdeniz, 2010). Her soru yazarının bu süreçlerin hepsini hatırlaması ve tam olarak uygulaması ve nitelikli bağlam temelli soru yazması yazarın tecrübelerinin ve deneyiminin de etkisiyle her zaman mümkün olmamaktadır (Kurnaz, 2013). Alan yazındaki çalışmaların sentez edilmesinden faydalanılarak bağlam temelli soru yazımı için gerekli olan ölçütlerin belirlenmesi bir gereklilik haline gelmiştir. $\mathrm{Bu}$ çalışma alandaki bu sıkıntılı durumu gidermek ve bağlam temelli soru yazımını daha sistematik bir hale getirmeyi amaçlamaktadır.

\section{Yöntem}

$\mathrm{Bu}$ çalışma bir derleme çalışması olup nitelikli bağlam temelli soru yazımı için gerekli olan ölçütlerin belirlenmesi için alan yazında var olan çalışmaların sonuçlarının sentez edilmesi ile oluşturulmuştur. Alan yazındaki bağlam temelli çalışmalar sistematik 
bir şekilde veri tabanlarından, dergilerden, kitaplardan ve benzeri kaynaklardan yapılan tarama sonucu toplanmıştır. Toplanan bu çalışmalar okunmuş ve üzerinde birçok tartışma yapılarak sonuçlarından nitelikli bağlam temelli soru yazımı için gerekli olan ölçütler çalışmanın yazarları tarafından oluşturulmuştur.

\section{Bağlam Temelli Bir Soru için Ölçütler ve Nedenleri}

Bir sorunun bağlam temelli olabilmesi için gerekli olan üç şart ve daha kaliteli bağlam temelli sorular hazırlayabilmek için bu üç şart ile ilgili alt maddeler Tablo 2'de özetlenmiştir. $\mathrm{Bu}$ alt maddelerin hepsi nedenleri ile birlikte tablonun altındaki başlıklarda açıklanacaktır. Bu üç temel şart aşağıda verilmiştir.

1. Bireyi ya da toplumu ilgilendiren bir sorun içermelidir.

2. Sorunun kurgusu yapılırken fen kavramları, formülleri ve kanunlarının bağlam ile bir örüntü içerisinde olması gereklidir.

3. Cevap yalnız ezber değil bir düşünme süreci sonucunda ortaya çıkmalıdır.

Bir sorunun bağlam temelli sayılabilmesi için yukarıdaki üç ölçüte mutlaka uyması gereklidir. Bununla birlikte bu ölçütlerin alt boyutları da vardır, soru ne kadar çok alt boyuta da uyarsa daha kaliteli bir bağlam temelli soruya dönüşür. 
Tablo 2

\section{Bağlam Temelli Sorular için Ölçütler}

\section{Bireyi ya da toplumu ilgilendiren bir sorun içermelidir.}

I.1. Soru hazırlanacak bağlamlar seçilirken bir ön çalışma yapılarak öğrencilerin ilgisini çeken bağlamlar belirlenebilir ve sorular bu bağlamlar üzerinden kurgulanabilir. Burada öğrencinin bağlamı tanıdıklığı ile birlikte bağlamın merak ve ilgi uyandıran bir bağlam olmasına dikkat edilmelidir.

I.2. Soru olabildiği kadar objektif yazılmaya çalışılmalıdır ve herhangi bir öğrenci grubunu kayırmamasına azami dikkat gösterilmelidir. Soru kurgulanırken seçilen bağlamın herhangi bir cinsiyeti, tecrübeyi vb. veya ölçtüğümüz şey dışındaki herhangi bir durumu kayırmamasına özen gösterilmelidir.

I.3. Öğrencileri duygusal olarak etkileyebilecek potansiyeli olan bağlamların kullanılmamasına özen gösterilmelidir. Soru öğrenciyi fen bilgisinden ziyade bağlama odaklamamalı ve bağlam çocukta duygusal bir dengesizlik yaratmamalıdır.

I.4. Sorudaki bağlam öğrencinin düzeyine uygun olmalı bununla birlikte öğrencinin de ilgisini çekecek şekilde kurgulanmış olmalıdır.

I.5. Odak olay ya da olayın gerçekleştiği sahne sorunu ortaya koyacak şekilde verilmelidir.

I.6. Öğrencilerin bu soruyu çözmesi için onlara bir motivasyon veya neden vermelidir.

\section{Sorunun kurgusu yapılırken fen kavramları, formülleri ve kanunlarının bağlam ile bir örüntü} içerisinde olması gereklidir.

II.1. Bağlam temelli soruların günlük hayatla olan ilişkisi açık net olmalı soru kurgusundaki veriler gerçekçi olmalıdır

II.2. Genelde bağlam temelli sorularda fen bilgisinin ve bağlamın ilişkisini göstermek için kısa hikâyeler kullanılabilir. Hikâyelerde gereksiz detaylardan kaçınılmalıdır.

II.3. Resim, diyagram ve figürler bağlam ve fen bilgisi arasındaki ilişkiyi güçlendirmek için kullanılmalıdır.

III. Cevap yalnız ezber değil bir düşünme süreci sonucunda ortaya çıkmalıdır.

III.1. Tek basamakta formüle sayıların yerleştirilmesi ile veya yalnızca ezbere dayalı bir bilgi ile çözülmez.

III.2. Bağlamlar kullanılarak hazırlanan soru aşırı zor veya aşırı kolay değildir.

Yukarıdaki verilen tablonun sistematiğine uygun olarak tüm ölçütler ve nedenleri aşağıda detaylı olarak açıklanmıştır.

I. Bireyi ya da toplumu ilgilendiren bir sorun içermelidir.

Nedeni: Bağlam temelli sorular gerçek hayatta karşılaşma ihtimalimiz olan sorunlar üzerinden kurgulanırlar. Özellikle günlük hayatta karşılaştığımız doğa olaylarının bağlam olarak kullanılması da tavsiye edilmektedir (Shiu-sing, 2005). Bununla birlikte düşünce gücümüzün sınırları içerisinde kurgulanan özellikle Einstein fiziği ile ilgili olarak da bağlam temelli sorular kurgulanabilir. Düşünce deneyleri bu tip sorulara güzel örneklerdendir. 
II. Sorunun kurgusu yapılırken fen kavramları, formülleri ve kanunlarının bağlam ile bir ilişki içerisinde olması gereklidir.

Nedeni: Fen bilgisi ve bağlam bilgisi soruda çok sıkı bir örüntü içerisinde kurgulanır. Bağlam ve fen bilgisi birlikte soru odağını oluşturmalıdır (Ahmed ve Pollitt, 2007). Sorun ancak bu fen bilgilerini kullanarak çözülebilmelidir.

III. Cevap yalnız ezber değil bir düşünme süreci sonucunda ortaya çıkmalıdır.

Nedeni: Hayatta karşılaşılan gerçek sorunlar genelde ezbere bilgilerle değil belirli düşünce süreçleri sonucunda çözülür. $\mathrm{Bu}$ sebeple bağlam temelli soruların sistematik düşünme süreçleri sonucu çözülmesi beklenir.

I.1. Soru hazırlanacak bağlamlar seçilirken bir ön çalışma yapılarak öğrencilerin ilgisini çeken bağlamlar belirlenebilir ve sorular bu bağlamlar üzerinden kurgulanabilir. Burada öğrencinin bağlama ne kadar tanıdık olduğu ile birlikte bağlamın merak ve ilgi uyandıran bir bağlam olmasına dikkat edilmelidir.

Nedeni: $\mathrm{Bu}$ durumun iki temel nedeni vardır birincisi öğrencinin bağlama ne kadar tanıdık olduğu diğeri de bağlamın öğrencileri ne kadar motive ettiği ve merak uyandırdığıdır. Bağlamı öğrencilerin günlük hayatlarında karşılaşma sıklığı ve bağlamla ilgili sahip oldukları bilgi birikimi bağlama tanıdıklık olarak tanımlanabilir. Türkiye'de yaşayan bir öğrenci için kriket sporunu bağlam olarak seçmek, Türkiye'de bu spor yaygın olmadığı için uygun olmayacaktır. Ön çalışma yapmak ve öğrencilerden farklı bağlamları ne kadar ilgilendiklerini ve merak ettiklerini sormak ve bu bağlamlar üzerinden soruları kurgulamakta öğrencilerin ilgi ve motivasyonları üzerinde olumlu etkilerde bulunacaktır. Bazen öğretmenlere ve soru hazırlayan kişilere ilginç gelen bağlamlar öğrencilere ilginç gelmemekte öğrenciler sorularda bağlamın kullanılmasının avantajını bu sebepten dolayı tam olarak yaşayamamaktadır (Elmas, Bülbül ve Ery1lmaz, 2011; Serin, 2009).

I.2. Soru olabildiği kadar nesnel yazılmaya çalışılmalıdır ve herhangi bir öğrenci grubunu kayırmamasına azami dikkat gösterilmelidir. Soru kurgulanırken seçilen bağlamın herhangi bir cinsiyeti, tecrübeyi vb. veya ölçtüğümüz şey dışındaki herhangi bir şeyi kayırmamasına özen gösterilmelidir.

Nedeni: $\mathrm{Bu}$ maddeye en güzel örnek cinsiyetlerin kayırılmasıdır. Özellikle erkekleri ya da özellikle kızları kayıracak şekilde kullanılan bağlamlar soruların çözümü sırasında cinsiyetlerden herhangi birini kayıracağı için soru ile ölçülmek istenen kazanım belli ölçüde gölgeleyebilir (Shiu-sing, 2005). Bağlam temelli sorular oluşturulurken herhangi bir cinsiyeti kayırmadan bağlam seçmenin ilk başlarda çok zor gibi görünmektedir ama bu konu ile ilgili çalışmalar yapılmıştır (Bülbül ve Matthews, 2012; Elmas, Bülbül ve Ery1lmaz, 2011). Bununla birlikte geliştirilen test boyunca farkl1 cinsiyet gruplarını kayıracağı düşünülen bağlamlar dengeli bir şekilde kullanılarak da bu sorunun üstesinden belli ölçüde gelinebilir (Serin, 2009).

I.3. Öğrencileri duygusal olarak etkileyebilecek potansiyeli olan bağlamların kullanılmamasına özen gösterilmelidir. Soru öğrenciyi fen bilgisinden ziyade bağlama odaklamamalı ve bağlam çocukta duygusal bir dengesizlik yaratmamalıdır. 
Nedeni: Ölüm, hastalıklar ve toplumda büyük yıkım etkisi yaratmış felaketlerin sorularda bağlamlar içinde kullanılması sırasında dikkatli olunmalıdır. Bu bağlamlar öğrencinin ilgisinden daha çok duyguları üzerinde etkili olabileceği için, öğrencinin dikkati fen bilgisinden ziyade bağlam üzerinde kalabilir ve öğrenci olumsuz etkilenebilir (Ahmed ve Pollitt, 2007). Bu tür bağlamlar öğretim materyallerinde kullanılsa bile sorularda kullanılmamasında fayda vardır. Buna örnek olarak 1999 yılında meydana gelen Gölcük depremi örnek olarak verilebilir. Kayıpların büyüklügünden dolayı toplumumuzu ciddi şekilde etkilemiştir (Ceyhan ve Ceyhan, 2006; Y1lmaz, 2004).

I.4. Sorudaki bağlam öğrencinin düzeyine uygun olmalı bununla birlikte öğrencinin de ilgisini çekecek şekilde kurgulanmış olmalıdır.

Nedeni: Öğrenciler sorudaki bağlamı anlayabilmeli ve durumu hayal edebilmelidir bu onları problemin çözümüne götüren ilk adımdır.

I.5. Odak olay ya da olayın gerçekleştiği ortam sorunu ortaya koyacak şekilde verilmelidir.

Nedeni: Ortam, soruyu ve fen bilgisini günlük hayatta ilişkilendiren unsurları içerdiği için açık, net ve gereksiz detaylardan uzak olarak soruda kurgulanmalıdır.

I.6. Öğrencilerin bu soruyu çözmesi için onlara bir motivasyon veya neden vermelidir.

Nedeni: Klasik fen sorularından farklı olarak bağlam temelli soruları çözerken öğrenciler aynı zamanda gerçek hayattan bir problemi çözüyormuş gibi hissedebilmeli ve çözüm için motive olmalıdırlar.

II.1. Bağlam temelli soruların günlük hayatla olan ilişkisi açık net olmalı soru kurgusundaki veriler gerçekçi olmalıdır.

Nedeni: Bağlam temelli soruların bir amacı da öğrencilerde okul bilgisi ve günlük hayat bilgisi diye iki ayrı bilgi odası varmış gibi davranmalarının önüne geçmektir (King, 2009). Günlük hayat ile ilişkili olan bağlam temelli soru kullanımı fen dersleri ile hayat arasında bağ kurabilmelerini sağlayacaktır. Bu sebeple fen bilgisi ile günlük hayattan kurgulanan bağlam arasında çok net ve açık bir ilişki olmalı günlük hayattan seçilen bağlam fen bilgisi kullanmayı gerektirmelidir (Benckert, 1997; Tekbıyık ve Akdeniz, 2010). Böylece fen derslerinde çözülen sorular, öğrencilerin hayatı daha kaliteli yaşamalarına da katkı sağlayacaktır.

II.2. Genelde bağlam temelli sorularda fen bilgisi ve bağlamın ilişkisini göstermek için kısa hikâyeler kullanılabilir. Hikâyelerde gereksiz detaylardan kaçınılmalıdır.

Nedeni: Bağlam temelli fen sorularıyla öğrencilerin Türkçe okuma becerilerini ölçmediğimiz açıktır bu sebeple sözel yükü çok fazla olan sorulara arka arkaya maruz kalmak öğrencileri yorabilmektedir. Bu sebeple soruyu oluşturduktan sonra soru da gereksiz detayların olup olmadığı mutlaka kontrol edilmelidir böylece sorunun geçerliliği de artırılmış olacaktır. 
Bağlam temelli sorularda klasik sorulara göre sözel yükün daha fazla olduğu bir gerçektir (Ahmed ve Pollitt, 2007). Öğretmen ve öğrencilerin bu durumdan genellikle rahatsız olmaktadırlar. Öğretmenler bu durumun bazı öğrencileri dezavantajlı duruma düşürebileceğini düşünmektedirler ve bu sebeple bağlam temelli soruları kullanmaktan kaygı duymaktadırlar (Rennie ve Parker, 1994). Öğrencilerde sorularda sözel yükün fazla olması soruyu daha zor gibi algilamalarına neden olmaktadır (Huntley, Ackerman ve Welch, 1989; Tekbıyık ve Akdeniz, 2010) ve bununla birlikte alış1k oldukları soru tarzından farklı olan bağlam temelli sorularda düşünüş şekli ve yorumlanması farklı olduğunu algısına kapılmaktadırlar (Rennie ve Parker, 1996). Sözel yükün fazla olduğu matematik sorularındaki başarıda cinsiyetler arasında istatistiksel olarak anlamlı bir başarı farkı bulunmamakla birlikte erkekler küçük farkla bayanlardan daha başarılı olmuşlardır (Huntley, Ackerman ve Welch, 1989).

II.3. Resim, diyagram ve figürler bağlam ve fen bilgisi arasındaki ilişkiyi güçlendirmek için kullanılmalıdır.

Nedeni: Bazen birçok kelime ile anlatmak istediğiniz bir ortamı veya durumu bir resimle anlatmak çok daha etkili ve verimli olur. Amacına uygun olarak kullanılan resim ve figürler sorulara ciddi derecede anlaşılabilirlik katabilir. Bununla birlikte sorularda gereksiz resim, diyagram ve figür eklemeleri ile uzatmak öğrencilerde soruların uzun ve zor olduğu ile ilgili bir algı oluşmasına da sebep olabilir. Bu noktada ihtiyaçlar iyi tespit edilmeli ve ona göre hareket edilmelidir.

III.1. Tek basamakta formüle sayıların yerleştirilmesi ile veya yalnızca ezbere dayalı bir bilgi ile çözülmemelidir.

Nedeni: Tek basamakta formüle sayıların yerleştirilmesi ile veya ezbere bir bilgi ile çözülebilecek bir soru için bağlam kullanmak anlamsızdır (Benckert, 1997). Bağlamsal sorular fen bilimleri ile günlük hayatın ilişkisini öğrenciye göstermeye çalışmaktadırlar ve genellikle günlük hayatta karşılaştığımız sorunların çözümüne tek basamakta gitmemiz zordur.

III.2. Bağlamlar kullanılarak hazırlanan sorular aşırı zor veya aşırı kolay olmamalidir.

Nedeni: Bağlam temelli soru hazırlama süreci ciddi bir emek ve beceri gerektiren bir süreçtir bu süreç sonunda oluşacak soruların ölçme değerlendirme süreçlerinde etkili bir şekilde kullanılmasının önüne geçebilecek durumların ortaya çıkmamasına dikkat edilmelidir.

\section{Bağlam Temelli Sorular ile ilgili Efsaneler}

Bağlam temelli sorular ile ilgili olarak doğru olmayan ama genel yarg1 oluşturmuş bazı yanlış algılar vardır. Bunların bir kısmını araştırmacıların tecrübeleri ile fark edilmiş bir kısmi ise alan yazın taraması sonucu ortaya çıkarılmıştır. 


\section{Bağlam Temelli sorular yalnız nitel olmalıdır:}

Bağlam temelli sorular hem nicel hem de nitel içerikli olabilir. Soru birden fazla basamakta çözülebilecek düşünme becerileri içererek formüller ve/veya yorumlanarak çözülebilir.

\section{2. İdealleştirilmiş sorulardaki nesneleri yalnızca günlük hayattan seçerek} soruyu bağlam temelli yapabiliriz:

$\mathrm{Bu}$ bağlam temelli olmayan ama kamufle edilmiş bağlam temelli sorular doğurur. Kamufle edilmiş bağlam temelli sorularda bağlam yerine kullanılan kavramı çıkardığımızda soru idealleştirilmiş bir soruya dönüşür ve soru herhangi bir şey kaybetmez.

Örnek kamuflajlı soru: Evlerde kullanılan elektrik sayaçlarının, tüketime ilişkin gösterdiği sayının birimi aşağıdakilerden hangisidir?

$\Omega(\mathrm{Ohm})$
A) J (Joule)
B) $\mathrm{kW}$ (Kilowatt)
C) C (Coulomb)
D) kWh (Kilowattsaat)

E)

3. Soru bir hikâye üzerinden kurgulanmışsa soru bağlam temelli sorudur:

Her hikâye üzerinden kurgulanan soru bağlam temelli olmayabilir bununla birlikte uzun sözlü anlatımlar sorularda çok dikkatli şekilde kullanılmalıdır.

\section{Sonuç ve Öneriler}

Yukarıda belirlenen ölçütler nitelikli bağlam temelli soru yazımı için bir rehber niteliğindedir. Belirlenen ölçütler kullanılarak kaliteli bağlam temelli sorular oluşturulabilir. Bağlam temelli soruların özellikle günlük hayatla içice olan fen bilimleri alanında etkin olarak kullanılmasının önemi açıktır. Sorular oluşturulurken günlük hayattan seçilen bağlamların karmaşıklık seviyeleri soru yazımı için indirgenirken çok dikkatli olunmalı ve bağlam örtücü ve kafa karıştırıcı değil anlaşılabilir ve ölçmeyle amaçlanan hedefe uygun şekilde kullanılmalıdır (Shiu-sing, 2005).

$\mathrm{Bu}$ noktada kritik olan öğrencilerimizin genelde idealleştirilmiş sorularla ölçme ve değerlendirme işlemine tabi tutulduğu ve bağlam temelli soruları kullanmaya onları alıştırarak başlamanın uygunluğudur (Cumming ve Maxwell, 1999). Bağlam temelli sorular ile hazırlanmış küçük sınavlarla başlanabileceği gibi alternatif olarak bağlam temelli sorular ve idealleştirilmiş sorular sınavlarda birlikte de kullanılabilir (Peşman ve Özdemir, 2012). Bağlam temelli sorular günlük hayatta karşılaştığımız tipte soru ve problemlere yakın oldukları için öğrencilerin günlük hayattaki problem çözme becerilerini de olumlu etkileyebilir. Bu sebeple özellikle fen bilimleri alanında çalışan akademisyenlerin kaliteli bağlam temelli soru yazımı konusunda bu rehber niteliğindeki çalışmayı etkin kullanmaları faydalı olacaktır. Bununla birlikte soru yazarları, ders kitabı yazarları ve öğretmenlerimizin bağlam temelli sorular oluştururken soru kalitesi açısından bu ölçütlerden faydalanmaları önemlidir. Özellikle ders kitaplarındaki etkinlikler ve sorular belirlenirken, etkinliklerin günlük hayatta kullanılan bağlamlardan seçilirken bu etkinlikleri ölçen soruların bağlam temelli olması kritik önem taşır. 
Bağlam temelli soru yazımı yapılırken özellikle bağlam ve fen kavramları arasındaki ilişki örüntüsünün çok güçlü olmasına dikkat edilmelidir. Bağlam ve soruda kurgulanan fen bilimleri kavramları iki ayrı yapı olarak düşünülmemelidir. Burada önce bağlamı seçip sonra bağlam üzerinde örüntü oluşturacak fen kavramları belirlenerek ilerlenmesinin daha etkili sonuçlar verecektir. Önce kavramların belirlenip sonra bağlam aranmasının daha yapay sonuçlar vermekte ve anlamlı bir örüntünün kurulması güçleşmektedir (Bellocchi, King, ve Ritchie, 2011). Bağlam temelli soru hazırlanırken her zaman ilk hedefin öğrencilerin performanslarının en iyi şekilde ölçülmesi olduğu unutulmamalı bu noktada sorunun örüntüsü oluşturulurken asıl amaçtan uzaklaşılmadığından emin olunmalıdır (Cumming ve Maxwell, 1999).

Diğer bir önemli noktada bağlam temelli sorular ile sınavlar hazırlanırken nicel ve nitel soru sayıları arasında bir denge olmalıdır. Yapılan çalışmalarda bağlam temelli nicel ve nitel soru tiplerinin farklı öğrenci gruplarını kayırabilir. Bu sebeple hazırlanan sorularda nitel ve nicel dengesine dikkat etmek faydalı olacaktır. Nitel bağlam temelli soruların nicellere göre daha dar kapsamlı fen kavramlarının kullanıldığı bir tartışma ortamı yarattığı bunun önüne geçilmesi içinde nitel sorular kurgulanırken şaşırtıcı bazı deneyimler içermeleri durumunda daha verimli oldukları belirlenmiştir (Benckert ve Petterson, 2008).

Bağlam temelli soruların kalitesinin, kullanımının ve sayısının artırılması eğitim sistemimiz için kritik bir öneme sahiptir. Bundan sonraki yapılan çalışmalarda yeni bağlam temelli soruların üretilmesi ve ülkemiz şartlarında uygulanması ve verimliliğinin, öğrenci başarısına etkisinin, cinsiyetleri kayırma durumu gibi faktörlerin incelenmesi ve somut delillerin üretilmesi bu çalışmadan bir sonraki adım olarak görülmektedir.

\section{Teşekkürler}

$\mathrm{Bu}$ çalışmanın hazırlanma aşamasında yapılan tartışmalardaki katkılarından ve metnin hazırlanması esnasında verdikleri geri bildirimlerden dolayı Yrd. Doç. Dr. Haki Peşman'a ve Yrd. Doç. Dr. M. Şahin Bülbül'e teşekkürlerimizi sunarız. 


\section{Kaynakça}

Ahmed, A. \& Pollitt, A. (2007). Improving the quality of contextualized questions: An experimental investigation of focus. Assessment in Education, 14(2), 201-232.

Akman, V. (2000). Rethinking Context as a Social Construct. Journal of Pragmatics, 32, 743-759.

Bellocchi, A., King, D., \& Ritchie, S. (2011). Assessing students in senior science: An analysis of questions in contextualised chemistry exams. In Lee, Kar Tin, King, Donna, Hudson, Peter B. and Chandra, Vinesh (Eds.), Proceedings of the 1st International Conference of STEM in Education 2010. Science, Technology, Engineering and Mathematics in Education Conference, Brisbane, Australia.

Benckert, S. \& Pettersson, S. (2008). Learning physics in small-group discussions-three examples. Eurasia Journal of Mathematics and Technology Education, 4(2), 121134.

Benckert, S. (1997). Conversation and context in physics education. Project Report 161/97, Swedish Council fort he Renewal of Higher Education.

Bennett, J., Lubben, F., \& Hogarth, S. (2007). Bringing science to life: a synthesis of the research evidence on the effects of context-based and sts approaches to science teaching. Science Education, 91, 347-370.

Broman, K., \& Parchmann, I. (2014). Students' application of chemical concepts when solving chemistry problems in different contexts. Chemistry Education Research and Practice, 15(4), 516-529.

Bülbül, M. Ş. \& Matthews, K. (2012) Bağlam Temelli Eğitimin Olası Geleceği , 548. X. Ulusal Fen Bilimleri ve Matematik Eğitimi Kongresi, Niğde, Turkey.

Ceyhan, E., \& Ceyhan, A. A. (2006). 1999 Marmara bölgesi depremlerini yaşayan üniversite öğrencileri üzerinde depremin uzun dönemli sonuçlari. Sosyal Bilimler Dergisi, 2, 197-212.

Christensson, C., \& Sjöström, J. (2014). Chemistry in context: analysis of thematic chemistry videos available online. Chemistry Education Research and Practice, 15(1), 59-69.

Cumming, J. J., \& Maxwell, G. S. (1999). Contextualising authentic assessment. Assessment in Education: Principles, Policy \& Practice, 6(2), 177-194.

Duranti, A., \& Goodwin, C. (Eds.) (1992). Rethinking Context: Language as an Interactive Phenomenon. Cambridge, UK: Cambridge University Press.

Elmas, R. (2012). The Effect of Context based Instruction on 9th Grade Students' Understanding of Cleaning Materials Topic and Their Attitude Toward 
Environment (Unpublished Doctoral Dissertation). Middle East Technical University, Turkey.

Elmas, R., Bülbül, M. Ş., \& Eryılmaz, A. (2011). Thematic classification of eligible contexts for a holistic perspective in curriculum development. Paper presented at European Science Education Research Association (ESERA), (s. 1-6). Lyon, France.

Gilbert, J. K. (2006). On the nature of “context” in chemical education. International Journal of Science Education, 28(9), 957-976.

Goffman, E. (1974). Frame analysis an essay on the organization of experience. Northeastern University Press, Boston: USA.

Gülyurdu, T. \& Eryılmaz, A. (2012). Meb onayli lise fizik ders kitaplarindaki sorularin yaşam temelli yaklaşima uygunluğunun araştirilmasi. Paper presented at Eğitimde ve Psikolojide Ölçme ve Değerlendirme III. Ulusal Kongresi, 19-21 Eylül, Bolu.

Heller P., Keith R. \& Anderson S. (1992). Teaching problem solving through cooperative grouping. part 1: group versus individual problem solving. American Journal of Physics, 60(7), 627-636.

Hill, A. M. (1998). Problem solving in real-life contexts: an alternative for design in technology education. International Journal of Technology and Design Education, 8(3), 203-220.

Huntley, R. M., Ackerman, T. A., \& Welch, C. (1989, March). Do verbal factors affect performance in mathematics tests? Paper presented at the Annual Meeting of the National Council on Measurement in Education, San Francisco.

King, D. (2009). Teaching and learning in a context-based chemistry classroom (Unpublished Doctoral Dissertation). Queensland University of Technology, Australia.

Kurnaz, M. A. (2013) Fizik öğretmenlerinin bağlam temelli fizik problemleriyle ilgili algilamalarinin incelenmesi. Kastamonu Eğitim Dergisi, 21(1), 375-390.

Mahaffy, P. (2015). Chemistry education and human activity. In Javier Garcia-Martinez \& Elena Serrano-Torregrosa (Eds.), Chemistry Education: Best Practices, Opportunities and Trends (1-26). USA: Wiley.

Peşman, H. (2012). Method-Approach interaction: the effects of learning cycle vs traditional and contextual vs non-contextual instruction on 11th grade students' achievement in and attitudes towards physics (Unpublished Doctoral Dissertation). Middle East Technical University, Turkey.

Peşman, H., \& Özdemir, Ö. F. (2012). Approach-Method interaction: the role of teaching method on the effect of context-based approach in physics instruction. International Journal of Science Education, 34(14), 2127-2145. 
Rennie, L. J. \& Parker, L. H. (1994, March). Barriers to teachers' reconstruction of their assessment practice. Paper presented at the Annual Meeting of the National Association for Research in Science Teaching, Anaheim, CA.

Rennie, L. J. \& Parker, L. H. (1996). Placing physics problems in real-life context: students' reactions and performance. Australian Science Teachers Journal, 42(1), $55-59$.

Serin, G. (2009). The Effect of problem based learning instruction on 7th grade students' science achievement, attitude toward science and scientific process skills (Unpublished Doctoral Dissertation). Middle East Technical University, Ankara, Turkey.

Shiu-sing, T. (2005). Some reflections on the design of contextual learning and teaching materials. Retrieved March, 15, 2015 from http://www.hkphy.org/contextual/approach/tem/reflect_e.html.

Sjöström, J., \& Talanquer, V. (2014). Humanizing chemistry education: from simple contextualization to multifaceted problematization. Journal of Chemical Education, 91(8), 1125-1131.

Tekbıyık, A. \& Akdeniz, A. R. (2010). Bağlam temelli ve geleneksel fizik problemlerinin karşilaştirilmasi üzerine bir inceleme. Necatibey Ĕ̌itim Fakültesi Elektronik Fen ve Matematik Ĕgitimi Dergisi (EFMED), 4(1), 123-140.

Tural, G. (2012). The Process of creating context based problems by teacher candidates. Procedia-Social and Behavioral Sciences, 46, 3609-3613.

Y1lmaz, V. (2004). A statistical analysis of the effects on survivors of the 1999 earthquake in turkey. Social Behavior and Personality, 32(6), 551-558. 